\title{
Detection of epitopes on follicle-stimulating hormone and FSH-antiserum-induced suppression of bioactivity of follicle-stimulating hormone and luteinizing hormone
}

\author{
W.E. Westhoff , J.W. Slootstraa, W.C. Puijk ${ }^{\mathrm{a}}$, D. Kuperus ${ }^{\mathrm{a}}$, \\ J.F. Flinterman ${ }^{b}$, W.M.M. Schaaper ${ }^{a}$, H.B. Oonk ${ }^{a}$, R.H. Meloen ${ }^{a, *}$ \\ "Institute for Animal Science and Health, Department of Molecular Recognition, P.O. Box \\ 65, $8200 \mathrm{AB}$ Lelystad, The Netherlands \\ 'Department of Endocrinology and Reproduction, Erasmus University Rotterdam, P.O. Box \\ 1738, 3000 DR Rotterdam, The Netherlands
}

Received 24 April 1995; revised 12 November 1995; accepted 12 December 1995

\begin{abstract}
There are currently two major approaches to hormonal male contraception. One relies on testosterone (analogs) either alone or in combination with gonadotropin releasing hormone (GnRH) (analogs or immunizations), the other on immunizations against follicle-stimulating hormone (FSH). Theoretically, the latter method will suppress spermatogenesis whilst not interfering with libido. An absolute requirement is, however, that an anti-FSH vaccine does not induce anti-luteinizing hormone ( $\mathrm{LH}$ ) antibodies ( $\mathrm{LH}$ being responsible for the induction of testosterone which is necessary to maintain libido). In this report we show that when whole FSH is used for vaccination, in most cases in addition to biological activity against FSH, anti-LH activity is also induced. By systematic analysis of the antisera raised with FSH using systematic epitope scanning (PEPSCAN) we found differences between the FSH-specific and FSH-nonspecific sera. Only the FSH-specific antiserum contained antibodies that recognized amino acid sequence $37-55$ on the $\beta$-subunit in a linear manner. Because antibodies against this epitope have not been found in the cross-reactive sera this epitope forms a prime candidate for an anti-FSH contraceptive vaccine
\end{abstract}

Keywords: FSH; Epitopes; Inhibition of biological activity; Male contraceptives: Immunization

* Corresponding author, Tel.: + 31320 238136; Fax: + 31320238050. 


\section{Introduction}

Up to the present, hormonal contraceptives for males are not available in a practically applicable form. A need exists for a larger diversity of methods, especially those producing long periods of effectiveness (Ada and Griffin, 1991). Several options are currently under investigation, which can be categorized in two different approaches (Wang et al., 1994). One approach concentrates on pharmacological methods (Cummings and Bremner, 1994). Treatment with GnRH analogs and/or testosterone analogs, which is the most developed method at present, has yielded good results, but the latter method awaits the development of long-acting and preferably orally active testosterone analogs (Weinbauer and Nieschlag, 1993; Weinbauer et al., 1994). A variety of non-hormonal substances have also been tested for their potential as a male anti-fertility agent, but non-reversibility and/or toxicity problems have precluded their practical use, as for example with gossypol (National coordinating group of male contraceptive studies, 1981). The second approach is the use of immunological methods. Two such methods have received attention recently. The first is vaccination against GnRH in combination with testosterone supplementation (Ladd et al., 1988). The second method is immunization with FSH (follicle stimulating hormone) which does not need (frequent) supplementation of testosterone. This method has been investigated less intensively for a number of practical reasons as outlined below. However, a contraceptive method in which spermatogenesis is selectively impaired without disturbing sexual functioning is most attractive. Therefore, the possibilities for the development of a contraceptive FSH-vaccine deserve more attention. For the development of male contraceptive vaccines much can be learned from the development of those for women, which are in far-advanced stages of development (Talwar, 1994; Talwar et al., 1994).

The use of FSH as a contraceptive vaccine goes back many years, when oFSH or its $\beta$-subunit were used to immunize rats and bonnet monkeys. All monkeys became oligospermic but no animal became azoospermic. However, none of the immunized animals was fertile as measured by the pregnancy-rate of proven fertile females (Moudgal, 1981; Murty et al., 1979). Thus, immunization against FSH or its $\beta$-subunit offers the possibility for use as a contraceptive vaccine in male primates, including humans.

FSH is a glycoprotein closely related to LH (luteinizing hormone), TSH (thyroid stimulating hormone) and CG (chorionic gonadotropin). Within a species these 4 hormones share a common $\alpha$-subunit and possess a distinct $\beta$-subunit which determines hormone specificity (Pierce and Parsons, 1981). Interspecies sequence homologies are generally high, ranging from $80-90 \%$ 
identical amino acids among $\alpha$-subunits and among $\beta$-subunits. The human $\alpha$-subunit is an exception, having a relatively low homology of $\sim 70 \%$ compared with the $\alpha$-subunits of other species (Fig. 1). The FSH $\beta$-subunits of different species also show considerable homology and, though to a lesser extent, there is also homology with the $\beta$-subunit of $\mathrm{LH}$. For hCG it has been shown that the $\alpha$ - and $\beta$-subunit although having low sequence homology share the same tertiary folding (Lapthorn et al., 1994; Wu et al., 1994). Therefore, the likelihood of developing cross-reactions is quite high. Moudgal (1981) does not, however, mention the cross-reactivity of antiFSH sera with LH. Murty et al. (1979) used passive immunization with sera cleared of anti-LH antibodies because these workers knew that the sera were raised with an LH-contaminated FSH preparation. In most reports describing epitope mapping of FSH mention is made that cross-reactive sera have been removed (e.g. Hojo and Ryan, 1985; Berger et al., 1988). However, the percentage of the FSH-antisera which are cross-reactive with LH is not given and in most reports cross-reactivity is not detected at the level of bioactivity.

We therefore investigated whether cross-reactivity is a problem by immunizing rabbits against FSH of ovine, human and bovine origin. The antisera were tested on inhibition of FSH and LH in bioassays. Furthermore, the sera were analyzed using systematic peptide-based methods (PEPSCAN) to analyze differences between FSH specific and non-specific sera.

\section{Materials and methods}

\subsection{Animals}

White New-Zealand rabbits and 3-week old Wistar rats were purchased from Charles-River Company, Germany and kept under standard laboratory conditions.

\subsection{Immunization protocol}

Two rabbits were immunized against ovine (o) FSH (R672 and R675) and 1 rabbit was immunized against human (h) FSH (R676). FSH was given in the amount of $10 \mu \mathrm{g}$, dissolved in phosphate buffered saline $\mathrm{pH}$ 7.2. hFSH and oFSH, for R672 only, were emulsified in complete Freund's adjuvant (CFA). The other oFSH vaccine (R675) was given adsorbed to aluminium hydroxide gel (alum). Boosters of the same amount were given 
in incomplete (I-)FA after 6 and 12 weeks in the CFA group and the alum rabbit was given boosters after 4 and 8 weeks. All vaccinations were given subcutaneously. The CFA-rabbits group were bled after 17 weeks and the alum rabbit after 14 weeks. These three raised antisera are abbreviated as o CFA, o alum and $h$ CFA, respectively, throughout this report. An antiserum against bFSH ( $\alpha \mathrm{bFSH})$ was a gift from Dr. Closset of Liège, Belgium. This antiserum was induced by immunizing a rabbit with bFSH emulsified in CFA intradermally. oFSH is NIADDK-oFSH16 AFP-5592C of the NIADDK-NIH, Bethesda MD, and hFSH is NIDDK-hFSH-I-SIAFP-1 AFP-5720D of the NIDDK-NIH, Bethesda MD.

\subsection{Immunological characterization of antisera}

FSH-ELISAs were done in 96-well plates (Greiner) as described by Berger et al. (1988) with the following modification: FSH ( $25 \mathrm{ng} /$ well) was coated in a $0.05 \mathrm{M} \mathrm{Na}_{2} \mathrm{CO}_{3}$ buffer $\mathrm{pH} 9.6$ for $1 \mathrm{~h}$ at $37^{\circ} \mathrm{C}$. Peptide ELISAs were done in similar plates. The wells were pre-coated with $0.2 \%$ glutaraldehyde in $0.1 \mathrm{M} \mathrm{NaH}_{2} \mathrm{PO}_{4}$ buffer $\mathrm{pH} 5$ for $4 \mathrm{~h}$ at $\mathrm{RT}$ while shaking. Plates were washed successively with the $\mathrm{pH} 5$ buffer; $0.1 \mathrm{M}$ $\mathrm{NaH}_{2} \mathrm{PO}_{4}$ buffer pH 6 and $0.1 \mathrm{M} \mathrm{Na}_{2} \mathrm{HPO}_{4}$ buffer $\mathrm{pH}$ 8. Peptides were dissolved in $\mathrm{pH} 8$ buffer $(1 \mu \mathrm{g} / 100 \mu \mathrm{l})$ and coated for $3 \mathrm{~h}$ at $37^{\circ} \mathrm{C}$. Plates were stored at $-20^{\circ} \mathrm{C}$ until use. The second antibodies were coupled to horseradish peroxidase (DAKO, Denmark) and ABTS (Boehringer, Mannheim) was used as the substrate. Antisera and second antibodies were diluted in buffer containing $4 \%$ horse serum.

The peptides used in the peptide ELISA are described in Table 1. The peptides were made on an ABI $430 \mathrm{~A}$ synthesizer $(0.25 \mathrm{mmol}$ scale $)$ or by hand $(0.015 \mathrm{mmol}$ scale) using Fast moc synthesis as described by Fields et al. (1991).

Dotblot assays were done by dotting $25 \mathrm{ng}$ of FSH per dot on nitrocellulose. Dotblots were dried overnight at RT after which the paper was stored at $-20^{\circ} \mathrm{C}$ until use. The antisera were analyzed on capability of detection of FSH as described by De Blas and Cherwinski (1983). The second antibodies were the same as those used in the ELISA.

Using the PEPSCAN method (Geijsen et al., 1984), antisera were tested for recognition of all overlapping 9- or 12-mer peptides of hFSH and oFSH. In short, all overlapping peptides of the same length of a protein are synthesized on polyethylene rods and these rods are tested in an ELISA procedure. In this way many peptides can be scanned for activity towards an antiserum. 


\subsection{Biological activity of antisera in vitro}

\subsubsection{Sertoli cell assay}

Sertoli cells were isolated from the testes of 3-week old Wistar rats as described by Oonk et al. (1985) with the following modifications. The isolation medium contained $5 \mathrm{mg} / \mathrm{l}$ DNAse (Sigma) and between the double collagenase digestion the tubular fragments were washed 4 times. The Sertoli cells were cultured in MEM (Eagle's MEM, Gibco, Grand Island, $\mathrm{NY}$, USA) with $2 \mathrm{mg}$ fungizone (Squibb, Princeton, $\mathrm{NJ}$ ), $1 \mathrm{mg}$ penicillin, 1 mg streptomycin, $10 \mathrm{ml}$ non-essential amino-acids (Gibco) and $10 \mathrm{ml}$ fetal calf serum per litre (MEM-FCS) in 24-well plates (Costar). On day 3 the cells were given a hypotonic shock with $10 \% \mathrm{MEM}$ for $2.5 \mathrm{~min}$ (Oonk and Grootegoed, 1987) after which the medium was replaced with MEM supplemented with $0.1 \%$ BSA (Sigma A-7888). On day 4 the cells were washed twice with MEM and incubated for $1 \mathrm{~h}$ in MEM supplemented with $4 \times 10^{-4} \mathrm{M}$ isobutylmethylxanthine (IBMX) (Sigma, St. Louis, MO), a phosphodiesterase inhibitor, and the substances to be tested. As a positive control, forskolin (Calbiochem) in a concentration of $10^{-5} \mathrm{M}$ was used. cAMP was measured with a cAMP RIA kit (Amersham).

For determination of $17 \beta$ estradiol $\left(E_{2}\right)$ synthesis the hypotonic shock was omitted and MEM-FCS was replaced on day 4. On day 7 the cells were washed twice with MEM and incubated in MEM-IBMX containing $4.5 \times$ $10^{-7} \mathrm{M}$ testosterone and the substances to be tested for $48 \mathrm{~h} . \mathrm{E}_{2}$ was

Table 1

Peptides used in the peptide ELISA

\begin{tabular}{|c|c|c|}
\hline $\mathrm{nr}$ & Sequence & Peptide \\
\hline 1 & ob $x 26-45$ & *GAPIYQCMGCCFSRAYPTPA \# \\
\hline 2 & $h \times 31-49$ & *CCFSRAYPTPLRSKKTMLV \# \\
\hline 3 & $o x 49-66$ & ${ }^{*}$ KTMLVPKNITSEATCCVA \# \\
\hline 4 & $r \times 69-85$ & *FTKATVMGNARVENHTE \# \\
\hline 5 & $\mathrm{~h} \times 73-92$ & GFKVENHTACHCSTCYYHKS \\
\hline 6 & $\mathrm{~h} / \beta 9-19$ & *TIAIEKEECRF \# \\
\hline 7 & ho/ $/ 28-40$ & ${ }^{*}$ CAGYCYTRDLVYK \# \\
\hline 8 & $\mathrm{~h} / 333-53$ & YTRDLVYKDPARPKIQKTCTF \# \\
\hline 9 & $\mathrm{~h} / 881-95$ & QCHCGKCDSDSTDCT \# \\
\hline
\end{tabular}

The numbering of the sequences is similar to the numbering in Table 2 . Before the sequence in one letter code the species is mentioned: $o$ is ovine, $b$ is bovine. $h$ is human and $r$ rat sequence; $x$ or $\beta$ subunit is indicated and the position of the peptide on the $x$ or $\beta$ subunit. Amino acids are indicated by the single letter code. *Indicates acetylation of the $\mathrm{N}$-terminus and \# indicates amidation of the C-terminus. 
measured with an RIA kit (DPC Laboratories, Los Angeles, CA). Total protein content of the wells was determined with the Lowry method (Lowry et al., 1951) using bovine serum albumin (Fraction V, Sigma) as the reference standard.

\subsection{2. hFSHR cell-line assay}

Y1 mouse adrenal cells, stably transfected with the cDNA for the human FSH receptor, were kindly donated by Ares Advanced Technology (Randolph, USA). These cells respond to FSH stimulation with cAMP accumulation, progesterone synthesis and a change in cell shape. Unstimulated cells grow flat on the surface, but after stimulation with a cAMP-stimulating agent the cells round off. This change in shape is maximal after $2-3 \mathrm{~h}$, disappears after $\sim 7 \mathrm{~h}$ and can easily be followed by light microscopy. The rounding off shows good correlation with the cAMP accumulation (data not shown). Cells were plated in 96-well plates in Ham's F10 medium (GIBCO) supplemented with $2 \mathrm{mM} \mathrm{L-glu-}$ tamine. The incubation was carried out in Ham's F10 medium. Concentrations of FSH used were: $\mathrm{hFSH}, 4 \mathrm{ng} / \mathrm{ml}$ and $\mathrm{oFSH}, 30 \mathrm{ng} / \mathrm{ml}$. Antisera were tested in various concentrations as indicated in the $\mathrm{Re}$ sults section. After 2 and $4 \mathrm{~h}$ the rounding off was examined.

\subsubsection{Leydig cell assay}

This assay was performed as described by van Haren et al. (1989). In short, a preparation of 24-day old rat Leydig cells in a concentration of $1 \times 10^{5}$ cells/well of a 48 -well plate was made. The cells were incubated on day 0 with a submaximal concentration of either oLH, hCG or hLH (all $1 \mathrm{ng} / \mathrm{ml}$ ) and with or without antiserum at a $1 / 100$ or $1 / 1000$ dilution. The incubation media further contained $5 \mu \mathrm{M}$ SU10603 and $5 \mu \mathrm{M}$ epostane to prevent metabolism of pregnenolone. The amount of pregnenolone was determined by RIA.

\subsection{Statistics}

Data for the Sertoli cell cultures cAMP- and $\mathrm{E}_{2}$-production were tested for significance by the Student-Newman-Keul's multiple comparisons test after one-way analysis of variance. 


\section{Results}

\subsection{Immunological activity of the FSH-aintisera}

All immunizations induced production of antibodies as determined by ELISA and dotblot (Table 2). In the ELISA the $x \mathrm{bFSH}$ antiserum cross-reacted with oFSH and $\mathrm{hFSH}$. In the dotblot assay the $\mathrm{h} C \mathrm{CFA}$ antiserum cross-reacted with oFSH. The $x \mathrm{bFSH}$ serum was not tested in the dotblot assay or in the Sertoli cell assay on $E_{2}$ formation or in the hFSHR assay due to limitation of the available amount of antiserum. Differences in cross-reactivity of the antisera between the two assay systems indicate that different epitopes are being exposed.

\subsection{Biological activity of the FSH-antisera}

The biological activity of the antisera in vitro was determined in Sertoli cell-, hFSHR cell- and Leydig cell assays (Table 2). All four antisera inhibited the bioactivity of FSH to some extent. In the Sertoli cell assay antisera were tested only against the species FSH with which they were raised, except the $x \mathrm{bFSH}$ antiserum which had to be tested against oFSH. We used oFSH because the ovine sequence displays the greatest similarity to the bovine amino acid sequence (Fig. 1), and bFSH was not available to us. The o alum antiserum inhibited only oFSH-induced cAMP accumulation and not oFSH-induced $\mathbf{E}_{2}$ formation, whereas the o CFA and $h$.FA antiserum could inhibit both FSH-induced cAMP accumulation and FSH-induced $\mathrm{E}_{2}$ formation. The h CFA antiserum displayed the most potent inhibition of FSH activity in both the Sertoli cell assay and the hFSHR assay. The o CFA antiserum, the o alum antiserum and the $x \mathrm{bFSH}$ antiserum inhibited oFSH activity in the hFSHR assay equally potently (Table 2 ).

More interspecies cross-reactions were observed in the bioassays than in the ELISA and dotblot assays. Both the o CFA antiserum and the $h$ CFA antiserum inhibited $o^{-}$and hFSH-stimulated change in cell shape. The antiserum against bFSH which recognized oFSH and hFSH in the FSH-ELISA was able to suppress oFSH-stimulated cAMP accumulation in the Sertoli cell assay at a 1/125 dilution (Table 2). Apparently, the cross-reactions in bioassays are determined by more and/or different epitopes than the cross-reactions found in ELISA and dotblot assays.

Functional cross-reactions with hLH, hCG or oLH were determined in the Leydig cell assay (Table 2). The o alum antiserum was the only serum 


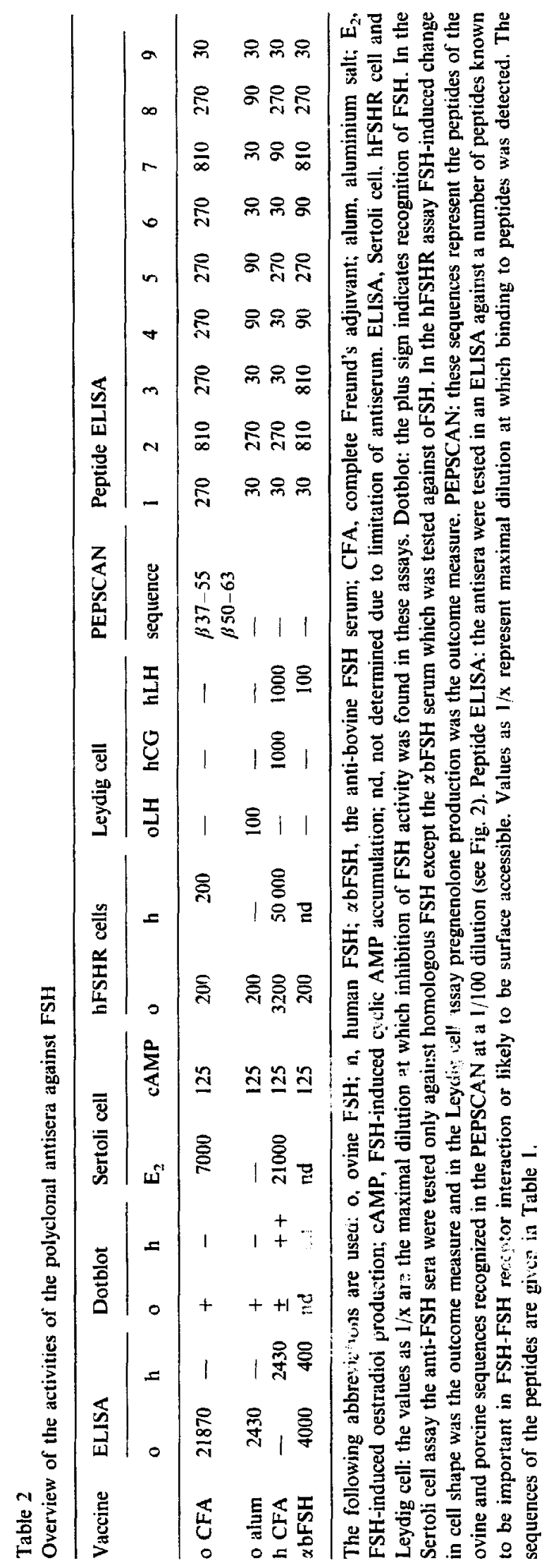




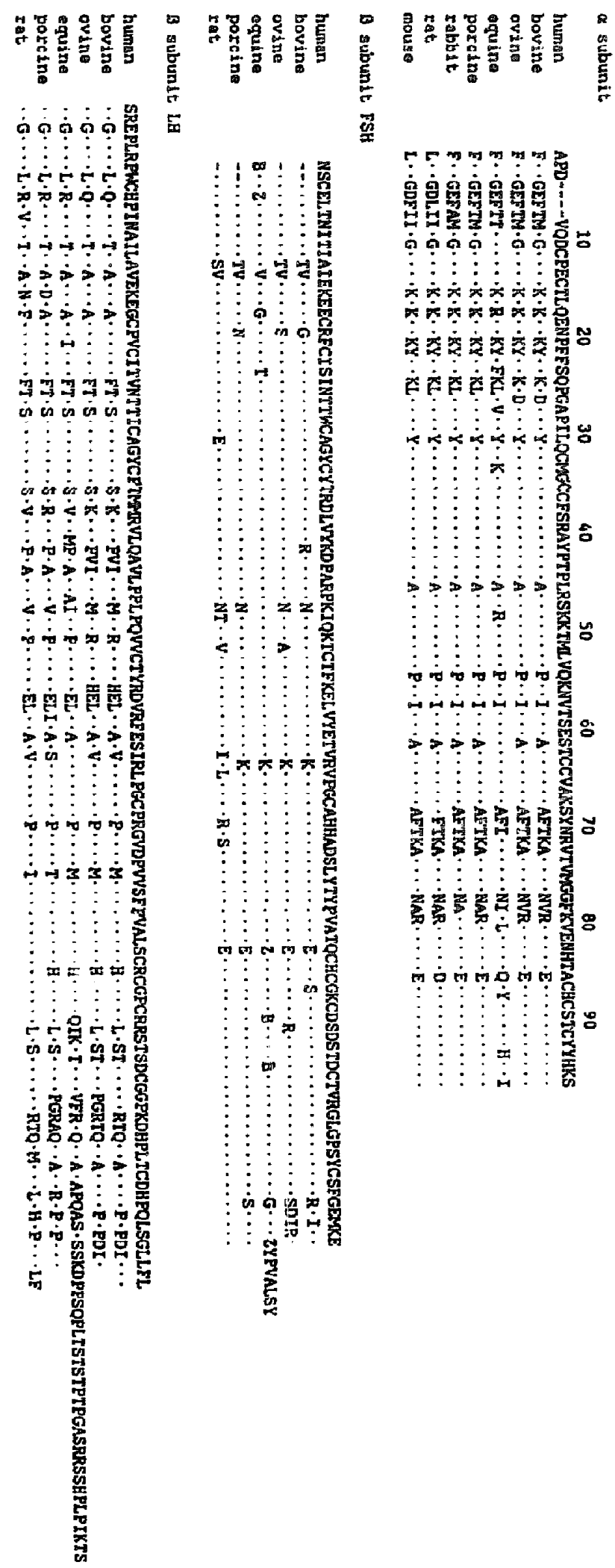

Fig. 1. Sequences of the $\alpha$ subunit and the $\beta$ subunits of FSH and LH of different species. Sequences were taken from the Swiss protein database. - = space introduced for alignment, $\cdot=$ amino acid identical to the human sequence. Note the many differences between human $\alpha$-subunit and the $\alpha$-subunits of other species in the first 15 amino acids and between amino acid 68 and 79. 
that inhibited oLH-induced pregnenolone production, whereas the $\mathrm{h}$ CFA antiserum was the only serum that inhibited hCG-induced pregnenolone production. Both $h$ CFA antiserum and the $\alpha b F S H$ antiserum inhibited hLH but the h CFA antiserum had greater potency. The o CFA antiserum was the only serum that did not crossreact with oLH, hLH or hCG.

\subsection{Epitope mapping of the FSH-antisera}

To detect possible differences between the sera cross-reactive in the Leydig cell assay and the o CFA antiserum not cross-reactive in this assay all four sera were scanned for epitopes. Two methods were used to map the epitopes, the PEPSCAN method and the peptide ELISA (Table 2). The PEPSCAN screenings of all four antisera against different FSH-sequences are also illustrated in Fig. 2. Significant antibody binding of the o CFA serum was found with peptides $\beta 37-48$ (VYKDPARPNIQK) to $\beta 44-55$ (PNIQKACTFKEL) (ovine sequence) which have the core sequence PNIQK, and peptides $\beta 50-63$ (FKELVYETVKVP). The epitope around peptide number 40 represents a part of the long loop (Lapthorn et al., 1994). The o CFA antiserum also recognized the corresponding peptides of the porcine sequence, whereas recognition of the human sequence was not significant. All other antisera did not show antibody binding to this set of peptides in the PEPSCAN. The three single peptide recognitions of $\alpha \mathrm{bFSH}$ antisera (one in the humseq PEPSCAN and two in the porcseq PEPSCAN) are most probably not representative of a linear epitope. A single peptide recognition is more likely the result of this peptide mimicking a discontinuous epitope.

In the peptide ELISA the binding of the antisera to different synthetic peptides representing parts of the FSH $\alpha$ - or $\beta$-subunits was measured (Table 2). These peptides (listed in Table 1) were chosen because they were expected to be solvent accessible, and the peptides $\alpha 73-94$ (carboxy terminus), $\beta 33-53$ (long loop) and $\beta 81-95$ (determinant loop) are considered to be important in FSH-receptor interaction (Yoo et al., 1993; Santa-Coloma et al., 1990; Campbell et al., 1991). The o CFA antiserum recognized all peptides except for the determinant loop. The sequences $2(\alpha 31-49)$ and 7 $(\beta 28-40)$ were recognized more strongly than the other peptides by the $o$ CFA antiserum. The o alum antiserum recognized peptides $2(\alpha 31-49), 4$ $(\alpha 68-85), 5(\alpha 73-92)$ and $8(\beta 33-55)$. The $\mathrm{h}$ CFA antiserum recognized peptides $2(\alpha 31-49), 5(\alpha 73-92), 7(\beta 28-40)$ and 8 ( $\beta 33-53)$. Recognition level of peptides by o alum- and h CFA antiserum was usually lower than by the o CFA antiserum. The $\alpha$ bFSH serum recognized peptides $2(\alpha 31-$ $49), 3(\alpha 49-66)$ and $7(\beta 28-40)$ strongly and reacted with peptides 4 

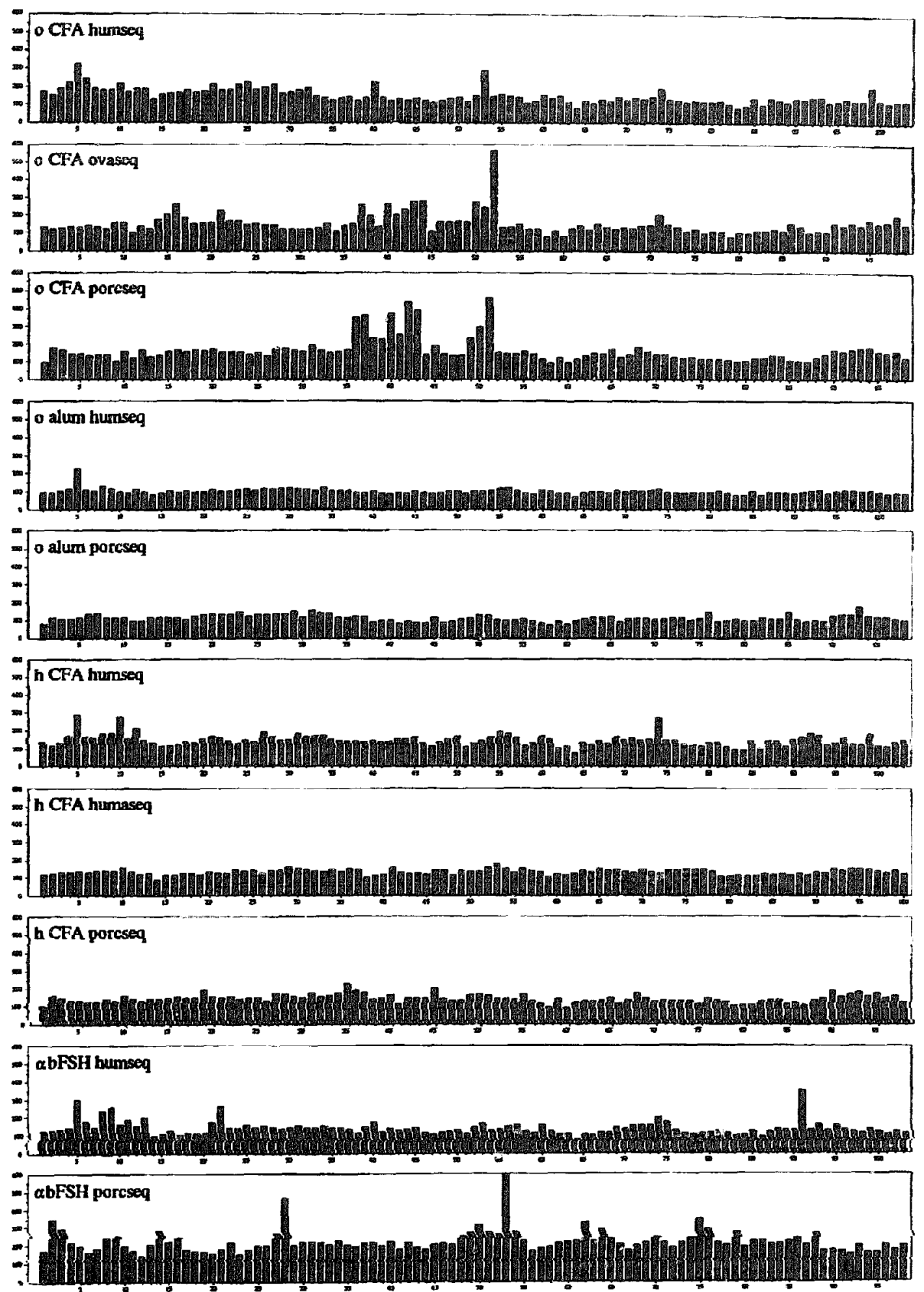

Fig. 2. PEPSCAN profiles of the antiserum obtained after immunization with oFSH emulsified in CFA (oCFA), of the antiserum obtained after immunization with oFSH adsorbed to aluminium gel (o alum), of the antiserum obtained after immunization with hFSH emulsified in CFA (h CFA) and the anti-bovine FSH serum ( $\alpha$ bFSH). The sera were tested in a 1/100 dilution against all overlapping 12-mer peptides of the $\beta$ chain of oFSH (ovaseq), all overlapping 12-mer peptides of the $\beta$ chain of porcine FSH (porcseq), all overlapping 12-mer peptides of the $\beta$ chain of human FSH (hlinaseq) or against all overlapping 9-mer peptides of the $\beta$-subunit of human FSH (humseq). The y-axis shows the optical density at $405 \mathrm{~nm}$. The $\mathrm{x}$-axis shows the short peptides ranked from the $\mathrm{N}$-terminus to the $\mathrm{C}$-terminus. 
$(\alpha 69-85), 5(\alpha 73-92), 6(\beta 9-19)$ and $8(\beta 33-53)$ at a level comparable to that of o CFA antiserum. In general, differences are found in the potency of the four antisera to recognize different peptides. However, for all antisera, binding to the entire FSH molecule was much stronger than binding to any of the FSH peptides.

\section{Discussion}

Immunization with FSH offers the possibility for use as a contraceptive vaccine in males. However, the chance of developing cross-reactivity with $\mathrm{LH}$ is quite high as these hormones share the same $\alpha$ subunit and have some sequence similarities between the $\beta$ subunits (Pierce and Parsons, 1981). Furthermore, at least for hCG, it is known that the $\alpha$ - and $\beta$-subunit have the same tertiary folding (Lapthorn et al., 1994; Wu et al., 1994). This report describes the epitope mapping of polyclonal intisera against FSH using an ELISA with short linear peptides and the PEPSCAN method. The ability of these antisera to inhibit the biological activity of FSH in two different bioassays and the anti-LH activity in a Leydig cell assay were also assessed. In our experiments all four antisera (two anti-ovine, one antiLovine and one anti-human FSH) were able to neutralize FSH in two bioassays. However, out of the four biologically active antisera only one exclusively inhibited FSH. The three other sera cross-reacted with LH/CG: one inhibited oLH, one inhibited hCG and one inhibited both hLH and hCG in a Leydig cell bioassay. The cross-reactions of the bioactive antiFSH antisera with hLH, oLH or hCG stress the necessity to design a peptide vaccine because only an FSH-specific peptide vaccine can prevent undesired cross-reactions with other hormones.

LH, CG (if present) and FSH share the same $\alpha$-subunit within a species whereas between most species the $\alpha$-subunit is well-conserved. However, the human $\alpha$-subunit is an exception, having a relatively low homology of $\sim 70 \%$ compared with the $\alpha$-subunits of other species (Fig. 1). The cross-reactions of the $o$ alum antiserum with oLH and the h CFA antiserum with $\mathrm{hCG}$ and $\mathrm{hLH}$ are therefore most likely mediated via epitopes on the $\alpha$-subunit which are not shared between ovine and human $\alpha$-subunits. The inhibition of hLH and not hCG by the $\alpha \mathrm{bFSH}$ antiserum can be explained in several ways. Firstly, the cross-reaction with hLH and not hCG could be mediate $\mathrm{i}$ by an epitope on hLH which is not shared with hCG and therefore must lie on the $\beta$-subunit or at the interface of the $\alpha$ - and $\beta$-subunit; however, these differences are likely to be small. Secondly, an epitope could be present on both hLH and hCG which is shielded on hCG 
by the carboxy terminal extension of hCG. Although the $\alpha \mathrm{bFSH}$ serum recognized peptide 3 ( $\alpha 49-66$ ovine sequence) this serum did not react with oLH. The most likely explanation for this puzzling result is that this epitope is exposed in a different way on the $x$ subunits of FSH and LH. The same applies to the o CFA antiserum which also, although at a lower level, recognized this peptide and did not cross-react with o $\mathrm{LH}$. The strong inhibition by $\mathrm{h} C \mathrm{CA}$ antiserum of $\mathrm{hFSH}$ and $\mathrm{hLH} / \mathrm{hCG}$ suggests that a high affinity receptor binding site is involved. According to the theory of Combarnous (1992), this site although not receptor specific, could lie on the $\alpha$-subunit together with the signal transducing site. For hCG (part of) this signal transducing site has been elegantly demonstrated by Ji et al. (1993). A second possibility is recognition of one or more epitopes comprising sugar residues which are also important in receptor activation (Sairam and Bhargavi, 1985). In contrast, the $\beta$-subunit bears a site with low affinity but high specificity for the receptor, namely $\beta 81-95$ (Campbell et al., 1991). In this theory $\beta 33-53$ is a second binding place though with stimulatory properties (Santa-Coloma and Reichert, 1990; Santa-Coloma et al., 1990). The sequence $\beta 81-95$ would be, based on its specificity, the most interesting for vaccination, however, in our experiments none of the antisera recognized this sequence.

The cross-reactions of the o alum-, $h$ CFA- and $\alpha \mathrm{bFSH}$ antisera with oLH or hCG and/or hLH cannot be mediated by epitopes represented by peptides 1-8 because these peptides are all well-recognized by the o CFA antiserum which does not cross-react with LH/CG. For one of these peptides nr 8 ( $\beta 33-55$ also known as the 'long' loop; Lapthorn et al., 1994) this lack of cross-reactivity was also observed by Labbé-Jullié et al. (1992) using TSH-peptides to elicit antipeptide antibodies. These authors found that the antiserum raised to TSH $\beta 31-51$ (the corresponding sequence of the long-loop in TSH) did not cross-react with FSH or $\mathbf{L H}$, in contrast to antisera to all other TSH-peptides. Reciprocally, it has to be confirmed that the long loop of FSH elicits antibodies that specifically neutralize FSH activity and do not cross-react with TSH or LH. The data above suggest that this is the case.

The long loop epitope has also been found by Butterstein et al. (1993) in vaccination experiments with $\beta$ FSH in female rats and by Vakharia et al. (1990), however, cross-reactivity with $\beta \mathrm{LH}$ was not examined. This site was not predicted by Krystek et al. (1985) who used a modification of the method of Hopp and Woods (1981) to predict immunogenic sites of the $\beta$-subunit of $\mathrm{hFSH}$ and oFSH. However, the site $\beta 9-19$, which is recognized by all antisera, was predicted using this method.

PEPSCAN analysis revealed one immune serum (o CFA) that specifically recognized the sequence $\beta 37-55$ (Table 2 ) which is considered important 
for FSH-receptor binding. One reason why only in one serum one epitope could be confirmed by PEPSCAN analysis could be that PEPSCAN analysis detects linear epitopes, but not discontinuous epitopes nor epitopes which include sugar residues. Another reason could be the length of the peptides. Longer peptides, having more similarity to $\mathrm{FSH}$, would probably be recognized more easily by the different antisera. Moudgal et al. (1989) observed that intact oFSH but not the $\beta$-subunit of oFSH could induce neutralizing antibodies, indicating that the correct conformation of FSH is necessary to obtain good antisera capable of inhibiting the biological activity of FSH. In this respect peptides might more closely resemble whole FSH than separate subunits, as the conformation of the subunits is strongly dependent on binding to each other (Strickland and Puett, 1982; Lustbader et al., 1987), whereas peptides are more flexible and in general do not possess a rigid conformation. For Foot and Mouth Disease Virus it has also been shown that immunization with peptides gives better results than immunization with separate subunits (Pfaff et al., 1982; Bittle et al., 1982). However, in the PEPSCAN method peptides are only 9 or 12 amino acids long, which might be too short to give the necessary resemblance to FSH, unless a linear epitope is present in the tertiary structure of FSH. In the structure described for hCG (Lapthorn et al., 1994; Wu et al., 1994) the long loop has indeed two parts (namely the two strands) which might expose linear epitopes. This might also explain why the observed epitope is divided in two parts (Fig. 2): the bend in the long loop is, of course, not linear.

Whereas cross-reactions between FSH, oLH and hCG are undesirable, cross-reactions between the FSHs from different species are warranted. In that case the epitope responsible for this cross-reaction can be used to immunize different species. The cross-reactivity of $h$ CFA antiserum with oFSH occurred via peptide $2(\alpha 31-49), 5(\alpha 73-92)$ and/or $8(\beta 33-53)$ and/or via discontinuous epitopes. The results of the peptide ELISA (Table 2) suggest that linear epitopes could be epitopes of both h CFA- and o CFA antisera. Cross-reactions quite often are used in assay kit systems to measure the amount of FSH of different species, but cross-inhibition of bioactivity of FSH has been little studied. Measurement of cross-reactivity in a bioassay is even more complicated than detection of cross-reactivity by other methods because, in addition to the interspecies cross-reactions, competition of antisera with the FSH-receptor for FSH also occurs. For instance, cross-reaction of oFSH antisera with hFSH competes for the native receptor (in the hFSHR assay) whereas in the reciprocal situation (hFSH antisera and oFSH) the receptor is also non-native. We found only low levels of interspecies cross-reactivity. However, in the successful experiments of Moudgal (1981) monkeys were immunized with oFSH, indicating 
that cross-reactivity was sufficiently strong to obtain a contraceptive vaccine.

In conclusion, we found that antisera induced to whole FSH in 3 out of 4 cases cross-reacted with $\mathrm{LH} / \mathrm{CG}$, showing that entire $\mathrm{FSH}$, in addition to being too costly, is unacceptable for use as a vaccine specifically and only suppressing spermatogenesis. Furthermore, we describe the delineation of an epitope of oFSH ( $\beta 37-55$, a part of the long loop) linked to the ability to inhibit FSH- but not LH bioactivity, and recognized in a linear context. These results suggest that the peptide $\beta 37-55$ may be a primary candidate to be used in a peptide vaccine able specifically to neutralize FSH in vivo.

\section{Acknowledgements}

We wish to thank the following persons and institutions for their contribution to this work: Dr. Closset for anti-bFSH antiserum; the National Hormone and Pituitary Program, NIDDK, Rockville, MD for oFSH and hFSH; Ares Advanced Technology, Randolph, USA for the Y1 cells and Ms D. Parohi for technical assistance. This work was supported by the Dutch organization for Scientific Research under grant number 901-15-033.

\section{References}

Ada, G.L. and Griffin, P.D. (1991) In: Vaccines for fertility regulation (Ada, G.L. and Griffin P.D., eds.), pp. XV-XVIII. Cambridge University Press, Cambridge.

Berger, P., Pannmoung, W., Khaschabi, D., Mayregger, B. and Wick, G. (1988) Antigenic features of human follicle stimulating hormone delineated by monoclonal antibodies and construction of an immuno-radiomometric assay. Endocrinology 123, 2351-2359.

Bittle, J.L., Houghton, R.A., Alexander, H., Shinnick, T.M., Sutcliffe, J.G., Lerner, R.A., Rowlands, D.J. and Brown, F. (1982) Protection against foot-and-mouth disease by immunization with a chemically synthesized peptide predicted from the viral nucleotide sequence. Nature 298, 30-33.

Butterstein, G.M., Sachar, D. and Dias, J.A. (1993) Immunoneutralization of heterodimeric FSH using FSH beta subunit as the immunogen. Am. J. Reprod. Immunol. 29, 48-55.

Campbell, R.K., Dean-Emig, D.M. and Moyle, W.R. (1991) Conversion of human choriogonadotropin into a follitropin by protein engineering. Proc. Natl. Acad. Sci. USA 88, $760-764$.

Combarnous, Y. (1992) Molecular basis of the specificity of binding of glycoprotein hormones to their receptors. Endocrine Rev. 13, 670-691.

Cummings, D.E. and Bremner, W.J. (1994) Prospects for new hormonal male contraceptives. Endocrinol. Metab. Clin. North Am. 23, 893-992.

De Blas, A.L. and Cherwinski, H.M. (1983) Detection of antigens on nitrocellulose paper immunoblots with monoclonal antibodies. Anal. Biochem. 133, 214-219. 
Fields, C.G., Lloyd, D.H., Macdonald, R.L., Otteson, K.M. and Noble, R.L. (1991) HBTU activation for automated Fmoc solid-phase peptide synthesis. Pept. Res. 4, 95-101.

Geijsen, H.M., Meloen, R.H. and Barteling, S.J. (1984) Use of peptide synthesis to probe viral antigens for epitopes to a resolution of a single amino acid. Proc. Natl. Acad. Sci. USA 81, 3998-4002.

van Haren, L., Cailleau, J. and Rommerts, F.F.G. (1989) Measurement of steroidogenesis in rodent Leydig cells: a comparison between pregnenolone and testosterone production. Mol. Cell. Endocrinol. 65, 157-164.

Hojo, H. and Ryan, R.J. (1985) Monoclonal antibodies against human follicle stimulating hormone. Endocrinology 117, 2428-2434.

Hopp, T.P. and Woods, K.R. (1981) Prediction of protein antigenic determinants from amino acid sequences. Proc. Natl. Acad. Sci. USA 78, 3824-3828.

Ji, I., Zeng, H. and Ji, T.H. (1993) Receptor activation of and signal generation by the lutropin/chorio-gonadotropin receptor. J. Biol. Chem. 268, 22971-22974.

Krystek, S.R., Dias, J.A., Reichert, L.E. Jr. and Andersen, T.T. (1985) Prediction of antigenic sites in follicle-stimulating hormones: difference profiles enhance antigenicity prediction methods. Endocrinology 117, 1125-1131.

Labbé-Jullié, C., Sergi, I., Canonne, C., Darbon, H. and Ronin, C. (1992) Comparative mapping of human thyrotropin, gonadotropins and free subunits with antipeptide antibodies. Endocrinology 131, 1999-2009.

Ladd, A., Prabhu, G., Tsong, Y.Y., Probst, T., Chung, W. and Thau R.B. (1988) Active immunization against gonadotropin-releasing hormone combined with androgen supplementation is a promising antifertility vaccine for males. Am. J. Reprod. Immunol. Microbiol. 17, 121-127.

Lapthorn, A.J., Harris, D.C., Littlejohn, A., Lustbader, J.W., Canfield, R.E., Machin, K.J., Morgan, F.J. and Isaacs, N.W. (1994) Crystal structure of human chorionic gonadotropin. Nature 369, 545-461.

Lowry, O.H., Rosebrough, N.J., Farr, A.L. and Randall, R.J. (1951) Protein measurement with the Folin phenol reagent. J. Biol. Chem. 193, 265-275.

Lustbader, J., Birken, S., Pollak, S., Levinson, L., Bernstine, E., Hsiung, N. and Canfield, R. (1987) Characterization of the expression products of recombinant human choriogonadotropin and subunits. J. Biol. Chem. 262, 14204-14212.

Moudgal, N.R. (1981) A need for FSH in maintaining fertility of adult male subhuman primates. Arch. Androl. 7, 117-125.

Moudgal, N.R., Sairam, M.R. and Dighe, R.R. (1989) Relative ability of ovine follicle stimulating hormone and its $\beta$-subunit to generate antibodies having bioneutralization potential in nonhuman primates. J. Biosci. 14, 91-100.

Murty, G.S.R.C., Sheela Pani, C.S., Moudgal, N.R. and Prasad, M.R.N. (1979) Effect of passive immunization with specific antiserum to FSH on the spermatogenic process and fertility of adult male bonnet monkeys. J. Reprod. Fertil. (suppl.) 26, 147-163.

National coordinating group of male contraceptive studies. (1981) Studies on the antifertility effect of gossypol, a new contraceptive for males. In: Recent advances in Fertility Regulation (Chang, C.F. and Griffen, D., eds.), pp. 122-146. S.A. Atar, Geneva.

Oonk, R.B., Grootegoed, J.A. and Molen, H.J. van der (1985) Comparison of the effects of insulin and follitropin on glucose metabolism by Sertoli cells from immature rats. Mol. Cell. Endocrinol. 42, 39-48.

Oonk, R.B. and Grootegoed, J.A. (1987) Identification of insulin receptors on rat Sertoli cells. Mol. Cell. Endocrinol. 49, 51-62. 
Pfaff, E., Mussgay, H.O., Schulz, F.E. and Schaller, H. (1982) Antibodies against a preselected peptide recognize and neutralize foot-and-mouth disease virus. EMBO J. 1, 869-874.

Pierce, J.G. and Parsons, T.F. (1981) Glycoprotein hormones: structure and function. Annu. Rev. Biochem. 50, 465-495.

Sairam, M.R. and Bhargavi, G.N. (1985) A role for glycosylation of the $x$ subunit in transduction of biological signal in glycoprotein hormones. Science 229, 65-67.

Santa-Coloma, T.A. and Reichert, L.E. Jr. (1990) Identification of a follicle-stimulating hormone receptor binding region in hFSH $\beta(81-95)$ using synthetic peptides. J. Biol. Chem. 265, 5037-5042.

Santa-Coloma, T.A., Dattatreyamurty, B. and Reichert, L.E. Jr. (1990) A synthetic peptide corresponding to human FSH $\beta$ subunit 33-53 binds to FSH receptor, stimulates basal oestradiol biosynthesis and is a partial antagonist of FSH. Biochemistry 29, 1194-1200.

Strickland, T.W. and Puett, D. (1982) $\alpha$-Subunit conformation in glycoprotein hormones and recombinant as assessed by specific antisera. Endocrinology $111,95-100$.

Talwar, G.P. (1994) Immuno-contraception. Curr. Opin. Immunol. 6, 698-704.

Talwar, G.P., Singh, O., Rahul, P., Chatterjee, N., Sahai, P., Dhall, K., Kaur, J., Das, S.K., Suri, S., Buckshee, K., Saraya, L. and Saxena, B.N. (1994) A vaccine that prevents pregnancy in women. Proc. Natl. Acad. Sci. USA 91, 8532-8536.

Vakharia, D.D., Dias, J.A., Thakur, A.N., Andersen, T.T. and O'Shea, A. (1990) Mapping of an assembled epitope of human follicle stimulating hormone- $\beta$ utilizing monoclonal antibodies, synthetic peptides, and hormone-receptor inhibition. Endocrinology 127, $658-666$.

Wang, C., Swerdloff, R.S. and Waites, G.M.H. (1994) Male contraception: 1993 and beyond. In: Contraceptive research and development 1984 to 1994 (Van Look, P.F.A. and Pérez-Palacios G., eds.), pp. 121-134. Oxford University Press, New Delhi.

Weinbauer, G.F. and Nieschlag, E. (1993) Gonadotrophin-releasing hormone analogue-induced manipulation of testicular function in the monkey. Human Reprod. 8, 45-50.

Weinbauer, G.F., Limberger, A. and Nieschlag, E. (1994) Can testosterone alone maintain the gonadotrophin-releasing hormone antagonist-induced suppression of spermatogenesis in the non-human primate. J. Endocrinol. 142, 485-495.

Wu, H., Lustbader, J.W., Liu, Y., Canfield, R.E. and Hendrickson, W.A. (1994) Structure of human chorionic gonadotropin at $2.6 \AA$ resolution from MAD analysis of the selenomethionyl protein. Structure 2, 545-558.

Yoo, J., Zeng, H., Ji, I., Murdoch, W.J. and Ji, T.H. (1993) COOH-terminal amino acids of the $\alpha$ subunit play common and different roles in human choriogonadotropin and follitropin. J. Biol. Chem. 268, 13034-13042. 